\title{
Correction to: Transitory ischemic attack associated with a rare fenestration of the cervical segment of the internal carotid artery: a case report
}

\author{
Christian Nasel ${ }^{1,2,3^{*}} \mathbb{D}$, Angelina Poetsch ${ }^{1}$, Cornelia Brunner ${ }^{4}$ and Ewald Moser ${ }^{3}$
}

\section{Correction to: J Med Case Reports (2022) 16:13} https://doi.org/10.1186/s13256-021-03227-0

Following publication of the original article [1], the authors reported errors in the contributing author names. The given name and family name were erroneously transposed.

The incorrect author names reads:

Nasel Christian

Poetsch Angelina

Brunner Cornelia

Moser Ewald

The correct author names should read:

Christian Nasel

Angelina Poetsch

Cornelia Brunner

Ewald Moser

The author group has been updated above and the original article [1] has been corrected.

\section{Author details}

'Department of Radiology, University Hospital Tulln, Karl Landsteiner University of Health Sciences, Alter Ziegelweg 10, A, 3430 Tulln, Austria. ${ }^{2}$ Department of Medical Imaging and Image -guided Therapy, Medical University of Vienna,

Vienna, Austria. ${ }^{3}$ Center for Medical Physics and Biomedical Engineering, Medical University of Vienna, Vienna, Austria. ${ }^{4}$ Department of Neurology, University Hospital Tulln, Karl Landsteiner University of Health Sciences, Tulln, Austria.

Published online: 28 February 2022

\begin{abstract}
Reference
1. Nasel C, Poestch A, Brunner C, et al. Transitory ischemic attack associated with a rare fenestration of the cervical segment of the internal carotid artery: a case report. J Med Case Rep. 2022;16:13. https://doi.org/10.1186/ s13256-021-03227-0.
\end{abstract}

\section{Publisher's Note}

Springer Nature remains neutral with regard to jurisdictional claims in published maps and institutional affiliations. permits use, sharing, adaptation, distribution and reproduction in any medium or format, as long as you give appropriate credit to the original author(s) and the source, provide a link to the Creative Commons licence, and indicate if changes were made. The images or other third party material in this article are included in the article's Creative Commons licence, unless indicated otherwise in a credit line to the material. If material is not included in the article's Creative Commons licence and your intended use is not permitted by statutory regulation or exceeds the permitted use, you will need to obtain permission directly from the copyright holder. To view a copy of this licence, visit http://creativecommons.org/licenses/by/4.0/. The Creative Commons Public Domain Dedication waiver (http://creativecommons.org/publicdomain/zero/1.0/) applies to the data made available in this article, unless otherwise stated in a credit line to the data. 